ФІНАНСОВІ РЕСУРСИ: ПРОБЛЕМИ ФОРМУВАННЯ ТА ВИКОРИСТАННЯ

УДК 336.13

DOI: $10.25140 / 2411-5215-2020-3(23)-93-100$

Максим Забаштанський, Дмитро Драгунов, Інна Зуб

\title{
ПРІОРИТЕТНІ ПІДХОДИ ДО ФІНАНСОВОГО ЗАБЕЗПЕЧЕННЯ СФЕРИ ОХОРОНИ ЗДОРОВ'Я В УКРАЇНІ
}

\author{
Максим Забаштанский, Дмитрий Драгунов, Инна Зуб
}

\section{ПРИОРИТЕТНЫЕ НАПРАВЛЕНИЯ ФИНАНСОВОГО ОБЕСПЕЧЕНИЯ СФЕРЫ ЗДРАВООХРАНЕНИЯ В УКРАИНЕ}

\author{
Maksym Zabashtanskyi, Dmytro Drahunov, Inna Zub \\ PRIORITY APPROACHES TO FINANCIAL SECURITY \\ OF HEALTHCARE IN UKRAINE
}

У статті розглянуто основні шляхи вдосконалення фінансового забезпечення сфери охорони здоров'я в Украӥні. Досліджено сучасні підходи до трактування дефініиії «медичне страхування», критичне узагальнення яких дозволило виокремити особливості їх застосування. Проаналізовано характерні риси медичного страхування за допомогою світового досвіду та здійснено ретельний розгляд їх застосування у провідних краӥнах світу. Акиентовано увагу на необхідності впровадження медичного страхування як одного з ключових інструментів у механізмі фінансового забезпечення сфери охорони здоров'я в Украӥні. Запропоновано відповідні заходи для покращення підходів до фінансового забезпечення сфери охорони здоров'я, які дозволили сформувати авторське бачення кониепиї медичного страхування в Украӥні.

Ключові слова: фінанси, фінансові ресурси; фінансове забезпечення; джерела фінансового забезпечення; сфера охорона здоров'я; медичне страхування.

Рис.: 2. Табл.: 1. Бібл.: 10.

В статье рассмотрены основные пути совершенствования финансового обеспечения здравоохранения в Украине. Исследованы современные подходы к трактовке дефиниции «медицинское страхование», критическое обобщение которых позволило выделить особенности их применения. Проанализированы характерные черты медицинского страхования с помощью мирового опыта и осуществлено тщательное рассмотрение их применения в ведущих странах мира. Акиентировано внимание на необходимости внедрения медицинского страхования, как одного из ключевых инструментов в механизме финансового обеспечения здравоохранения в Украине. Предложен ряд мер для улучшения подходов к финансовому обеспечению сферы здравоохранения, которые позволили сформировать авторское видение кониепчии медицинского страхования в Украине.

Ключевые слова: финансы; финансовые ресурсы; финансовое обеспечение; источники финансового обеспечения; сфера здравоохранение; медицинское страхование.

Рис.: 2. Табл.: 1. Библ.: 10.

The article considers the main ways to improve the financial security of health care in Ukraine. Modern approaches to the interpretation of the definition of "health insurance" are studied, the critical generalization of which allowed to highlight the features of their application. The characteristic features of health insurance with the help of world experience are analyzed and their application in the leading countries of the world is carefully considered. Emphasis placed on the need to introduce health insurance as one of the key tools in the mechanism of financial support of health care in Ukraine. A number of measures have been proposed to improve approaches to the financial provision of health care, which have formed an author's vision of the concept of health insurance in Ukraine.

Keywords: finance; financial resources; financial security; sources of financial security; health care; health insurance.

Fig.: 2. Table: 1. References: 10.

JEL Classification: G20; G22

Постановка проблеми. У сучасних умовах значної глобалізації економіки та прискорення темпу життя суспільства, охорона здоров'я відіграє надзвичайно важливу роль збереження здорової нації, а також виступає ключовим елементом її національної безпеки.

Сфера охорони здоров'я в України нині обмежена в можливості надання послуг належної якості всім верствам населення, що насамперед зумовлено наявністю значного фізичного та морального зносу основних засобів, спричинених відсутністю достатніх обсягів фінансового забезпечення спрямованого на інноваційне технологічне оновлення та модернізацію протягом останніх років. Крім того, низький рівень оплати праці лікарів та медичного персоналу, спричиняє відтік кваліфікованих фахівців зі сфери, що здійснює подальше загострення питання надання медичних послуг належної якості. Саме тому впровадження медичного страхування $є$ альтернативним шляхом вдосконалення процесу фінансового забезпечення сфери охорони здоров'я в Україні.

(C) Забаштанський М. М., Драгунов Д. М., Зуб I. М., 2020 
Аналіз останніх досліджень і публікацій. Питання фінансового забезпечення сфери охорони здоров'я в Україні досліджуються вітчизняними та закордонними вченими. Значний внесок у вивчення особливостей фінансового забезпечення зробили Я. Буздуган, В. Виговська, О. Гонта, В. Демянишин, М. Дубина, О. Кириленко, В. Москаленко, М. Мних, В. Маргасова, С. Онишко, Н. Ткаченко, С. Юрій та багато інших науковців.

Виділення недосліджених частин загальної проблеми. Попри фундаментальність проведених досліджень, питання інноваційного розвитку сфери охорони здоров'я, розширення можливих джерел фінансового забезпечення сфери за допомогою медичного страхування набувають дедалі більшого значення та актуальності, що суттєво загострилось в умовах сучасної пандемії COVID-19.

Метою цієї статті $є$ дослідження альтернативних джерел і шляхів фінансового забезпечення сфери охорони здоров'я в Україні шляхом впровадження обов'язкового та добровільного медичного страхування з метою покращення якості медичних послуг та забезпечення інноваційного розвитку цієї сфери в Україні.

Виклад основного матеріалу. Однією з ключових функцій держави є забезпечення здорової нації в країні через сферу охорони здоров'я, результативність функціонування якої перебуває в площині належної якості медичних послуг та тривалості життя населення. Водночас забезпечення належної якості медичного обслуговування безпосередньо залежить від обсягів фінансового забезпечення $з$ державного бюджету, який у сучасних умовах неспроможний покрити іiі наявні потреби в повному обсязі. Саме тому значна увага науковців та практиків приділяється саме медичному страхуванню як додатковому джерелу іiі фінансового забезпечення. Система медичного страхування в Україні на сьогодні не $\epsilon$ достатньою поширеною, оскільки під страхуванням більшість населення розуміє нещасні випадки, під час настання яких страхова компанія відшкодовує потерпілій особі вартість лікування. Медичне страхування є однією зі складових у системі страхової медицини. Медичне страхування у сфері охорони здоров'я пов'язано із забезпеченням громадян якісними та доступними медичними послугами. Враховуючи обмеженість бюджетного фінансування, з одного боку, а також низький рівень доходів переважної частини населення - 3 іншого, обов'язкове медичне страхування може стати вагомим додатковим джерелом фінансового забезпечення сфери охорони здоров'я. На сьогодні медичне страхування може залучити додаткові фінансові ресурси для повноцінної організації медичної допомоги населенню.

Нині в науково-практичній літературі наявні різні підходи до трактування дефініції «медичне страхування». Значна когорта науковців визначає під ним «страхування на випадок втрати здоров'я з будь-якої причини, зокрема через хворобу та нещасний випадок». Деякі науковці, такі як І. Астахова трактує їі як «спосіб страхування, при якому населення зможе отримати якісні медичні послуги чи діагностику в разі виникнення проблем зі здоров'ям» [1, с. 109].

3 економічного погляду враховуючи сучасний стан фінансового забезпечення сфери охорони здоров'я в Україні, впровадження обов'язкового медичного страхування є актуальним та обгрунтованим. Ефективне медичне страхування є однією з найважливіших складових національних систем охорони здоров'я. Соціальний пакет медичного страхування $\epsilon$ соціальним захистом у сфері охорони здоров'я, який гарантує забезпечення медичною допомогою при будь-яких обставин, зокрема у зв'язку із захворюванням або нещасним випадком. До теперішнього часу наявний значний перелік джерел фінансового забезпечення сфери охорони здоров'я, але три основні види фінансування мають ключове значення: державне, обов'язкове та добровільне медичне страхування. На сьогодні більшість країн світу використовує як обов'язкове, так і добровільне медичне страхування. Розглядаючи сучасні форми й методи медичного страхування (рис. 1) треба зазначити, що такий розподіл створює сприятливі умови для розвитку і подальшого використання медичного страхування, що призведе до якісного та швидкого надання медичних послуг. 
ФІНАНСОВІ РЕСУРСИ: ПРОБЛЕМИ ФОРМУВАННЯ ТА ВИКОРИСТАННЯ

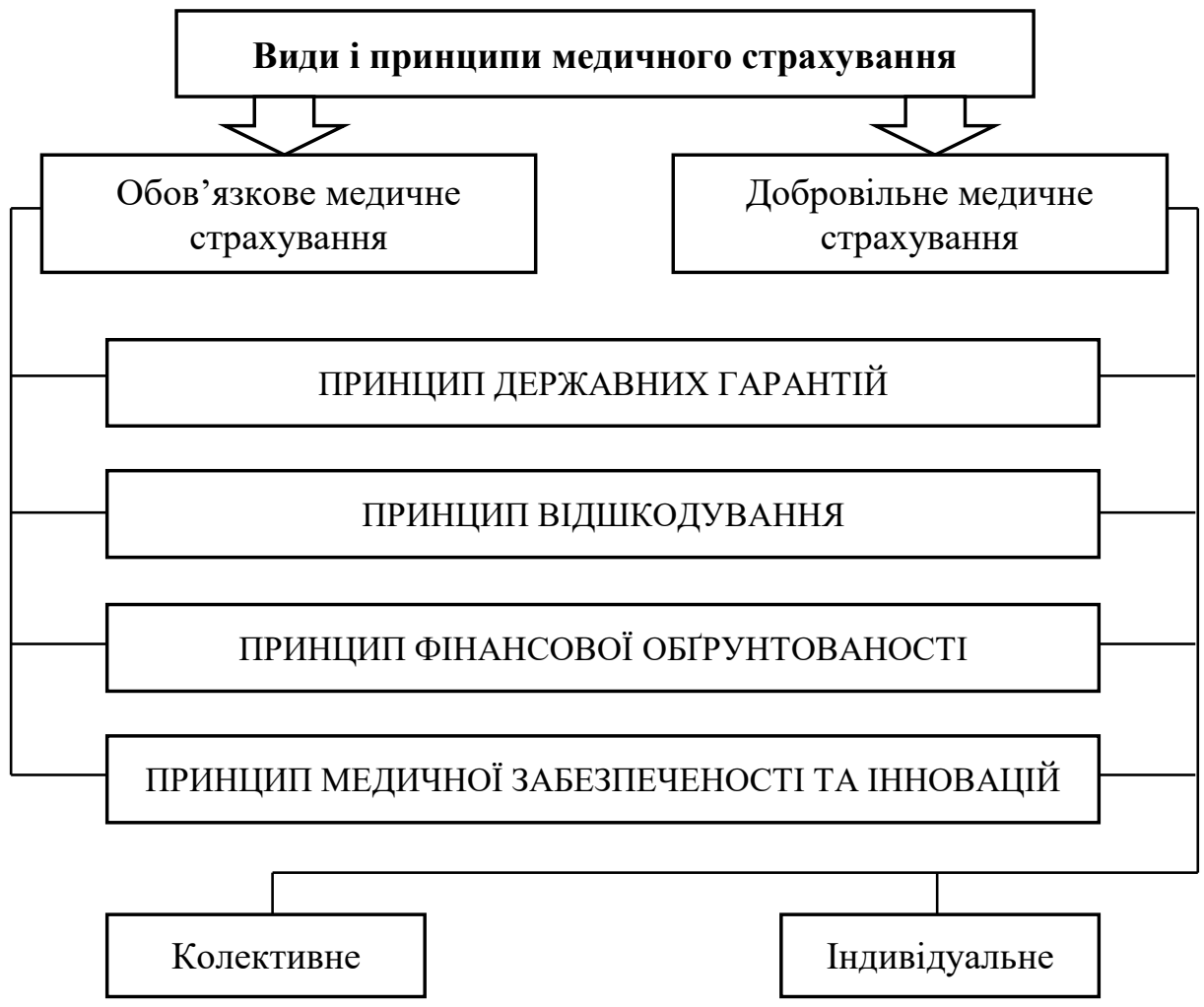

ВІДШКОДУВАННЯ СТРАХОВИХ ВИПАДКІВ

смерть застрахованої особи внаслідок хвороби під час перебування в медичному за- ушкодження здоров'я внаслідок нещасного випадку хвороба застрахованої особи

Рис. 1. Сучасні види та принциии медичного страхування

За видами медичне страхування поділяється на обов'язкове й добровільне, в основі якого перебуває група принципів фінансового забезпечення:

- державних гарантій - забезпечення наявності пакету обов'язкового медичного страхування для всіх соціально незахищених верств населення за рахунок бюджетного фінансування на умовах повної або часткової оплати;

- повного та своєчасного відшкодування фінансових ресурсів - здійснення державного контролю в частині гарантування вчасної сплати страховими компаніями страхових виплат у разі настання страхового випадку за наявними договорами обов'язкового та добровільного медичного страхування з метою повного та своєчасного забезпечення населення необхідними медичними послугами;

- принцип фінансової обгрунтованості - вартість послуг обов'язкового та добровільного медичного страхування повинна забезпечувати стимулювання фінансових інтересів усіх учасників цих відносин, а також виступати своєрідним «імпульсом» для розвитку медичного страхування, у частині належного фінансового забезпечення медичної сфери, зростання якості медичних послуг, а також розвитку національної економіки;

- принцип медичної забезпеченості та обов'язковості - гарантування медичною установою своєчасної та повної первинної та вторинної медичної допомоги в разі наявності у громадянина поліса обов'язкового або добровільного медичного страхування; 
- принцип інноваційного фінансування - пріоритетне спрямування медичними установами сформованих у результаті розвитку системи обов'язкового та добровільного страхування наявних фінансових ресурсів на інноваційне оновлення медичного обладнання 3 метою якісного та своєчасного надання медичних послуг.

Держава має гарантувати стійкість цієї системи, а також виконання зобов'язань перед застрахованими громадянами.

Перехід до обов'язкового медичного страхування в Україні є пріоритетним напрямом удосконалення фінансового забезпечення сфери охорони здоров'я, що перевірено світовим досвідом і сприятиме підвищенню якості, доступності та своєчасного діагностування та надання медичної допомоги населенню [2, с. 35].

Впровадження обов'язкового медичного страхування в існуючих умовах трансформації фінансових відносин повинно бути забезпечено державною підтримкою. Забезпечення населення необхідними медичними послугами на сьогодні є достатньо вартісним у порівнянні 3 реальними доходами населення, проте в умовах обмеженості державного фінансування повне надання пакета медичних послуг є суттєво ускладненим. Держава не в змозі забезпечити надання допомоги в разі захворювання. У цьому випадку систему обов'язкового медичного страхування доповнює система добровільного медичного страхування.

Добровільне медичне страхування виступає важливим сучасним компонентом та ефективним доповненням до системи соціального забезпечення, зокрема й обов'язкового медичного страхування.

Добровільне медичне страхування поділяється на індивідуальне та колективне. За індивідуальним страхуванням виступають окремі громадяни, які уклали договір зі страховою компанією про страхування себе або своїх дітей чи батьків за рахунок власних грошових коштів. При колективному страхуванні об'єктом страхування $\epsilon$ підприємство чи установа, яка укладає договір зі страховою компанією про страхування своїх працівників або інших фізичних осіб за рахунок фінансових ресурсів компанії.

Страхові організації, які займаються страхуванням, укладають угоди з лікувальними закладами (незалежно від форм власності) про надання ними медичної допомоги, перелік яких повинен бути зазначений у договорі страхування, а також сума страхового платежу в разі настання страхового випадку.

Поліс із добровільного медичного страхування передбачає обсяг надання медичних послуг та можливість вибору умов отримання медичної допомоги. Розширення програми добровільного медичного страхування дає можливості для покращення умов надання профілактичної, лікувально-діагностичної та реабілітаційної допомоги, що впливає на якість медичних послуг [6].

Фінансове забезпечення сфери охорони здоров'я в різних країнах світу здійснюють зазвичай у змішаній формі з урахуванням наявних джерел фінансового забезпечення. Систему охорони здоров'я називають державною (Англія, Ірландія, Італія, Шотландія), обов'язкового медичного страхування (Бельгія, Нідерланди, Німеччина, Швеція, Японія) та змішаною (бюджетно-страховою) (США), де близько 90 \% населення країни користуються послугами приватних страхових компаній [4].

Медичне страхування повинно бути впроваджено в Україні з урахуванням наявних трансформацій у цій сфері, з метою забезпечення формування змішаної бюджетнострахової системи фінансування охорони здоров'я в Україні. Досить цікавим із таких позицій є дослідження закордонного досвіду змішаного фінансування для забезпечення ефективної діяльності сфери охорони здоров'я, проте його практичне впровадження повинно бути адаптованим до вітчизняних реалій (таблиця). 
Світовий досвід медичного страхування провідних краӥн світу

\begin{tabular}{|c|c|}
\hline Країна & Обгрунтування медичного страхування \\
\hline Німеччина & $\begin{array}{l}\text { У країні є децентралізація, зміст якої полягає в тому, що в країні існує понад } 1000 \text { стра- } \\
\text { хових кас, професійних та територіальних, які несуть обов'язковий медичний характер. }\end{array}$ \\
\hline Англія & $\begin{array}{l}\text { В Англії превалювання бюджетної системи фінансування, обов'язковим медичним страху- } \\
\text { ванням охоплено } 1 / 3 \text { населення країни та пацієнти платять тільки } 10 \text { \% вартості лікування }\end{array}$ \\
\hline США & $\begin{array}{l}\text { Американська модель медичного страхування характеризується акумуляцією коштів у } \\
\text { централізованому страховому фонді, розподілом яких займається централізований фонд } \\
\text { на основі законодавчо встановленої форми розрахунків. Охоплюється понад } 20 \text { \% насе- } \\
\text { лення. Добровільним груповим страхуванням за місцем роботи охоплюється близько } \\
60 \text { \% населення }\end{array}$ \\
\hline $\mathbf{K}$ & $\begin{array}{l}\text { У Канаді медичне страхування є обов’язковим. Суспільні фонди покривають } 90 \text { \% всіх } \\
\text { затрат на лікування, а за рахунок оподаткування покриваються } 25 \text { \% всіх затрат на охоро- } \\
\text { ну здоров’я }\end{array}$ \\
\hline Японія & $\begin{array}{l}\text { Японська модель медичного страхування характеризується наявністю двох програм: } \\
\text { обов’язкового медичного страхування та державного. Медичне страхування охоплює всіх } \\
\text { працюючих на підприємствах } 3 \text { кількістю зайнятих п’ять і більше осіб, а також членів } \\
\text { їхніх сімей }\end{array}$ \\
\hline
\end{tabular}

Джерело розроблено автором на основі $[3 ; 4 ; 7 ; 9 ; 10]$.

Аналіз світового досвіду провідних країн світу в частині впровадження медичного страхування засвідчує, що в дуже незначній кількості країн держава може дозволити собі повне фінансове забезпечення функціонування сфери охорони здоров'я виключно за рахунок бюджетного фінансування. У більшості країн намагаються ввести медичне страхування і поєднувати різні системи фінансування системи охорони здоров'я, оскільки в сучасних умовах якість надання медичних послуг з метою збереження здоров'я громадян є ключовими пріоритетами розвитку.

Добровільне медичне страхування є формою захисту інтересів громадян у разі захворювання з будь-якої причини. Воно пов'язане 3 компенсацією громадянами грошових коштів, які вони витратили на оплату медичної допомоги, та інших витрат, пов'язаних із підтримкою здоров’я, такі як: відвідуванням медичних спеціалістів та амбулаторне лікування; придбанням медичних ліків; лікуванням у стаціонарі; отриманням стоматологічної допомоги; проведенням профілактичних та діагностичних оздоровчих заходів [10].

Кількісні показники добровільного медичного страхування в Україні з кожним роком зростають, про що свідчить рівень укладених договорів та сум страхових платежів. На сьогодні на ринку працюють понад 30 страхових компаній і вже середній рівень виплат становить більше ніж 60 \%. Страхові компанії пропонують різні програми, які забезпечують населення медичним обслуговуванням відповідної якості [8].

Незважаючи на це, вартість медичного страхування для переважної частини населення залишається досить значною. На сьогодні середня вартість страхових послуг медичного страхування перебуває в межах 10000 грн на людину в рік, якщо до пакета медичних послуг входить повний комплекс послуг: невідкладна допомога, поліклінічне обслуговування, лікування в стаціонарі й забезпечення медичними ліками на всіх етапах лікування.

Першими кроками запровадження медичного страхування повинно стати нормативне закріплення обов'язкового медичного страхування, створення на рівні міст і селищ, там де надають первинну медичну допомогу, що є основою для формування нової моделі медичного страхування сфери охорони здоров'я в Україні (рис. 2).

Розвиток та подальше практичне впровадження медичного страхування здійснюється 3 метою формування достатнього обсягу фінансового забезпечення інноваційного оновлення як системи первинної медичної допомоги, так і забезпечення розвиток усієї сфери загалом з метою покращення якості медичних послуг та забезпечення безперервного функціонування сфери, особливо в умовах сучасної пандемії COVID-19. 


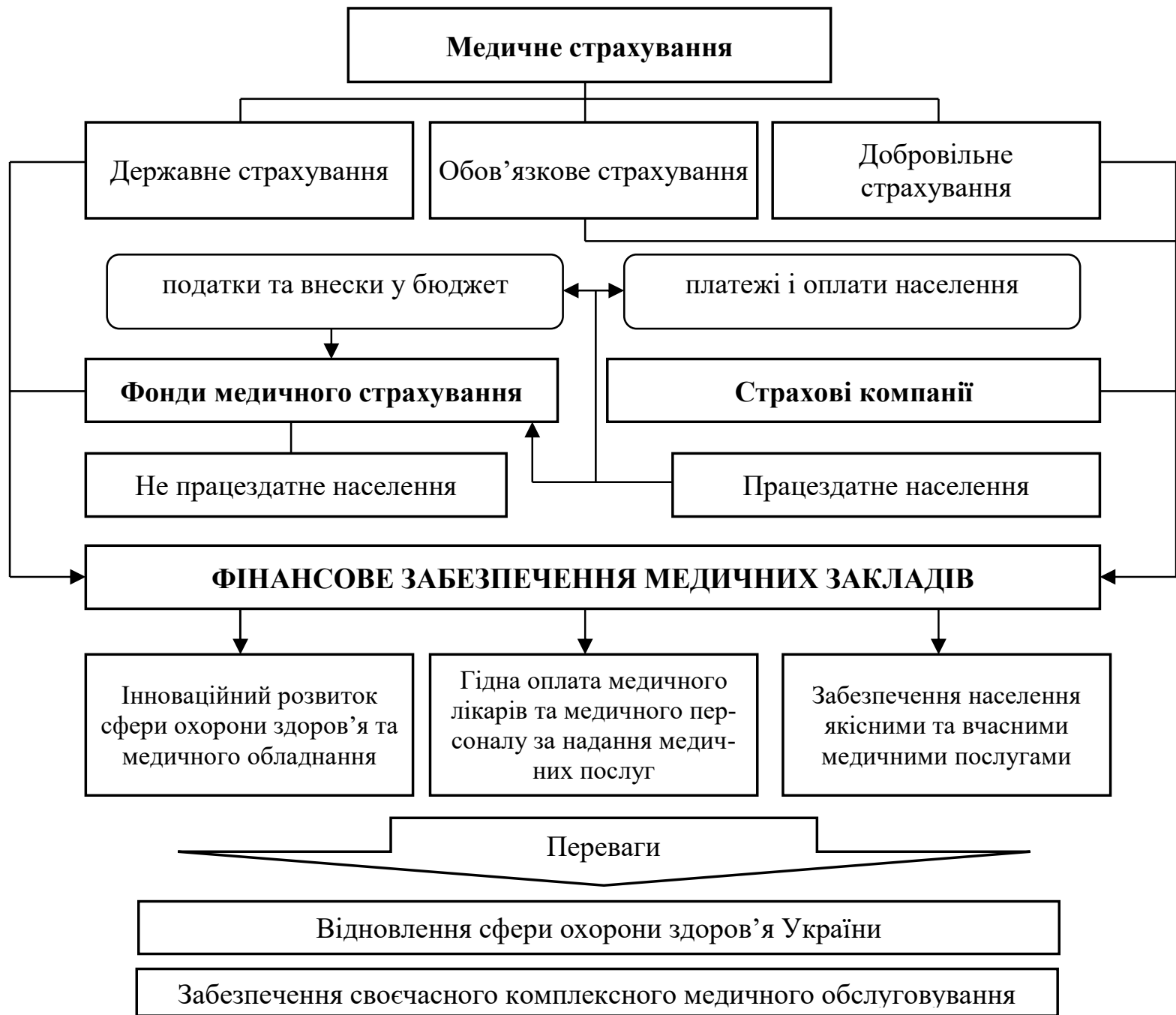

Підвищення тривалості життя населення та підвищення продуктивності

Забезпечення передумов сталого розвитку національної економіки

Рис. 2. Конщептуальна модель медичного страхування в Украйні

Передусім держава повинна зробити перші кроки в нормативній базі щодо впровадження обов'язкового державного страхування, а також забезпечити фінансову підтримку верств населення з низьким рівнем доходів. Окремого підходу до страхування, а також його фінансового забезпечення потребує медичне страхування непрацездатного населення, дітей у віці до 16 років та людей похилого віку, які не в змозі в повному обсязі здійснювати оплату цього страхування. Гарантування державою мінімального пакета медичних послуг перебуватиме у площині обов'язкового медичного страхування, що дасть змогу забезпечити доступ усіх верств населення до кваліфікованої та сучасної медичної допомоги, а також проведення вчасної діагностики з метою попередження можливої хвороби.

Державне страхування в умовах недостатнього фінансування необхідно для створення надійного фінансового забезпечення сфери охорони здоров'я. Надання медичної допомоги при надзвичайних ситуаціях має бути доступним для всіх, що передбачає забезпечення мінімального пакета якісних медичних послуг.

3 метою розвитку сфери охорони здоров'я, а також забезпечення іiї подальшого ефективного функціонування доцільним $є$ впровадження таких заходів: 
ФІНАНСОВІ РЕСУРСИ: ПРОБЛЕМИ ФОРМУВАННЯ ТА ВИКОРИСТАННЯ

- розгляд на загальнодержавному рівні та нормативне закріплення обов'язкового медичного старування, як ключового джерела фінансового забезпечення сфери та ії інноваційного розвитку;

- розробка механізму часткової компенсації вартості обов'язкового медичного страхування для малозабезпечених верств населення, а також осіб з обмеженими можливостями;

- подальший розвиток страхових фондів добровільного медичного страхування за рахунок залучення соціально-відповідальних підприємств до добровільного медичного страхування їх працівників;

- створення страхових фондів медичного страхування за рахунки добровільних страхових внесків працівників та робочих організацій (індивідуальних та колективних).

Згідно з економічними розрахунками, проведеними М. Мних, обов'язкове медичне страхування забезпечить надходженню до бюджету більше ніж 8 млрд грн на рік. Незважаючи на помітні переваги, його запровадження в Україні затримується, що пов'язано з відсутністю єдиного підходу до законопроєкту про обов'язкове медичне страхування [5]. Проте саме медичне страхування дає можливості та великі переваги у формуванні необхідних джерел фінансового забезпеченням сфери охорони здоров'я спрямованого на забезпечення відповідної якості медичних послуг.

Висновки і пропозиції. Сфера охорони здоров'я в Україні потерпає від недостатності фінансового забезпечення. Значна кількість внутрішніх суперечностей і нестабільність держави не можуть гарантувати високий рівень надання медичних послуг. Впровадження обов'язкового медичного страхування $є$ необхідним, оскільки сфера охорони здоров'я України перебуває у низькому стані фінансового забезпечення. Медичне страхування, як обов'язкове, так і добровільне дозволить здійснити послідовний перехід до якісного та доступного медичного обслуговування, що в результаті дасть поштовх у зростанні та процвітанні сильної та здорової нації.

\section{Список використаних джерел}

1. Астахова I. Е., Касьян С. О. Перспективи загальнообов'язкового медичного страхування в Україні. Фінансово-кредитна діяльність: проблеми теорії та практики. 2009. № 1. С. 111-115.

2. Болдова А. А., Мойко В. Й. Особливості медичного страхування в Україні. Збірник наукових праць Національного університету державної податкової служби України. 2012. № 2. С. 33-39.

3. Забаштанський М. М. Концептуальні підходи до формування політики фінансового забезпечення суб'єктів господарювання комунальної сфери. Актуальні проблеми економіки: науковий економічний журнал. 2010. № 1(103). С. 103-108.

4. Коваль О. А., Ночвай О. І. Проблеми та перспективи впровадження медичного страхування в Україні. Ефективна економіка. 2014. № 4. URL: http://www.economy.nayka.com.ua/?op=1\&z=2905.

5. Мних М. В. Медичне страхування та необхідність його запровадження в Україні. Економіка та держава. 2009. № 2. С. 40-41.

6. Хмельницкий С. И. Медицинская реформа в Украине. URL: http://hospital_sem@mail.ru.

7. Медичне страхування 2020. URL: https://ukr.segodnya.ua/ukraine/s-kazhdogopo-400-grn-vmesyac-v-ukraine-predlagayut-vvestimedicinskoe-strahovanie-1182586.html.

8. Новосельська Л. І. Шляхи запровадження медичного соціального страхування в Україні. Науковий вісник. 2009. № 18. С. 82-85.

9. Яковлева Т. Соціально-правові передумови запровадження обов'язкового медичного страхування. Підприємництво, господарство і право. 2008. № 11. С. 71-74.

10. Ялтинська кооперація. Медичне страхування в Україні. Страхова справа. 2006. № 3. C. $60-61$.

\section{References}

1. Astahova I. E., Kasyan V. O. (2009). Perspectyvy zagalnooboviazcovogo medychnogo strahuvannia [Prospects for compulsory health insurance in Ukraine]. Finansovo credytna diialnist: problemy teorii ta practyky - Financial and credit activities: problems of theory and practice, 1, pp. 111-115. 
2. Boldova A. A., Moiko V. I. (2012). Osoblyvosti medychnogo strahuvfnnia v Ukraini [Features of health insurance in Ukraine]. Zbirnyk naukovyh prats Natsionalnogo universytety derzhavnoi podatkovoi slyzhby Ukrainy - Collection of scientific works of the National University of the State Tax Service of Ukraine, 2, pp. 33-39.

3. Zabashtanskyi M. M. (2010). Kontseptualni pidhody do formuvannia polityky finansovogo zabezpetsennia subektiv gospodaruvannia komunalnoi sfery [Conceptual approaches to the formation of financial security policy for utilities]. Aktualni problem ekonjmiky - Current economic problems, 1(103), pp. 103-108.

4. Koval O. A., Nochvai O. I. (2014). Problemy ta perspektyvy vprovadzhtnnia medychnogo strahuvannia v Ukraine [Problems and prospects for the introduction of health insurance in Ukraine]. Efektyvna ekonomika - Efficient economy, 4. http://www.economy.nayka.com.ua/?op=1\&z=2905.

5. Mnyh M. V. (2009). Medychne strahuvannia ta neobhidnist ogo zaprovadzhennia v Ukraini. [Health insurance and the need for its introduction in Ukraine]. Ekonomika ta derzhava - Economy and state, 2, pp. 40-41.

6. Hmelnitskii S.I. (2019). Medstsinskaia reforma v Ukraine [Medical reform in Ukraine]. http://hospital_sem@mail.ru.

7. Medychne strahuvannia [Medical Insurance]. (2020). https://ukr.segodnya.ua/ukraine/skazhdogopo-400-grn-v-mesyac-v-ukraine-predlagayut-vvestimedicinskoe-strahovanie-1182586.html.

8. Novoselska L. I. (2009). Shlahi zaprovadzhtnnia medychnogo sotsialnogo strahuvannia v Ukraine [Ways to introduce medical social insurance in Ukraine]. Naukovi visnyk - Scientific Bulletin, 18 , pp. 82-85.

9. Iakovleva T. (2008). Sotsialno pravovi peredumovy zaprovadzhennia oboviazkovogo medychnogo strahuvannia [Socio-legal preconditions for the introduction of compulsory health insurance]. Pidpryemnytstvo, gospodarstvo i pravo - Entrepreneurship, economy and law, 11, pp. 71-74.

10. Yalta cooperation. Medychne strahuvannia v Ukraine [Yaltynska kooperatsiia. Medical insurance in Ukraine]. (2006). Strahova sprava - Insurance business, 3, pp. 60-61.

Забаштанський Максим Миколайович - доктор економічних наук, професор, директор Навчальнонаукового інституту бізнесу, природокористування і туризму, Національний університет «Чернігівська політехніка» (вул. Шевченко, 95, м. Чернігів, 14035, Україна).

Забаштанский Максим Николаевич - доктор экономических наук, профессор, директор Учебно-научного

института бизнеса, природопользования и туризма, Национальный университет «Черниговская политехника» (ул. Шевченко, 95, г. Чернигов, 14035, Украина).

Zabashtanskyi Maksym - Doctor of Economic Sciences, Professor, Director Educational-Scientific Institute of Business, Environtal Management and Tourism, Chernihiv Politechnic National University (95 Shevchenka Str., 14035 Chernihiv, Ukraine).

E-mail: mazani@ukr.net

ORCID: http://orcid.org/ 0000-0002-8966-8116

ResearcherID: G-6145-2014

Драгунов Дмитро Миколайович - аспірант кафедри управління персоналом та економіки праці, Національний університет «Чернігівська політехніка» (вул. Шевченка, 95, м. Чернігів, 14035, Україна).

Драгунов Дмитрий Николаевич - аспирант кафедры управления персоналом и экономики труда, Национальный университет «Черниговская политехника» (ул. Шевченко, 95, г. Чернигов, 14035, Украина).

Drahunov Dmytro - PhD student of the Department of Personnel Management and Labor Economics, Chernihiv

Politechnic National University, (95 Shevchenka Str., 14035 Chernihiv, Ukraine).

E-mail: drahunovdm@gmail.com

ORCID: http://orcid.org/0000-0002-3828-8914

Зуб Інна Миколаївна - аспірант кафедри управління персоналом та економіки праці, Національний університет «Чернігівська політехніка» (вул. Шевченка, 95, м. Чернігів, 14035, Україна).

Зуб Инна Николаевна - аспирант кафедры управления персоналом и экономики труда, Национальный университет «Черниговская политехника» (ул. Шевченко, 95, г. Чернигов, 14035, Украина).

Zub Inna - PhD student of the department of Personnel Management and Labor Economics, Chernihiv Politechnic

National University, (95 Shevchenka Str., 14035 Chernihiv, Ukraine).

E-mail: follow777up@gmail.com

ORCID: http://orcid.org/0000-0003-1825-1847

Забаштанський М., Драгунов Д., Зуб І. Пріоритетні підходи до фінансового забезпечення сфери охорони здоров'я в Україні. Проблеми і перспективи економіки та управління. 2020. № 3(23). С. 93-100. 